\title{
Integration of multiple climate models to predict range shifts and identify management priorities of the endangered Taxus wallichiana in the Himalaya-Hengduan Mountain region
}

\author{
Peixian $\mathrm{Li}^{1,2} \cdot$ Wenquan $\mathrm{Zhu}^{1,2} \cdot$ Zhiying $\mathrm{Xie}^{1,2} \cdot \mathrm{Kun}^{\mathrm{Qiao}}{ }^{1,2}$
}

Received: 14 December 2018/Accepted: 13 May 2019/Published online: 10 July 2019

(C) The Author(s) 2019

\begin{abstract}
Taxus wallichiana Zucc. (Himalayan yew) is subject to international and national conservation measures because of its over-exploitation and decline over the last 30 years. Predicting the impact of climate change on $T$. wallichiana's distribution might help protect the wild populations and plan effective ex situ measures or cultivate successfully. Considering the complexity of climates and the uncertainty inherent in climate modeling for mountainous regions, we integrated three Representative Concentration Pathways (RCPs) (i.e., RCP2.6, RCP4.5, RCP8.5) based on datasets from 14 Global Climate Models of Coupled Model Intercomparison Project, Phase 5 to: (1) predict the potential distribution of $T$. wallichiana under
\end{abstract}

Project funding: The work was supported by the National Natural Science Foundation of China (Grant Nos. 41630750, 41771047) and the State Key Laboratory of Earth Surface Processes and Resource Ecology (Grant No. 2017-FX-01(1)).

The online version is available at http://www.springerlink.com.

Corresponding editor: Tao $\mathrm{Xu}$.

Electronic supplementary material The online version of this article (https://doi.org/10.1007/s11676-019-01009-5) contains supplementary material, which is available to authorized users.

Wenquan Zhu

zhuwq75@bnu.edu.cn

1 State Key Laboratory of Earth Surface Processes and Resource Ecology, Beijing Normal University, Beijing 100875, People's Republic of China

2 Beijing Engineering Research Center for Global Land Remote Sensing Products, Institute of Remote Sensing Science and Engineering, Faculty of Geographical Science, Beijing Normal University, Beijing 100875, People's Republic of China recent past (1960-1990, hereafter "current") and future (2050s and 2070s) scenarios with the species distribution model MaxEnt.; and (2) quantify the climatic factors influencing the distribution. In respond to the future warming climate scenarios, (1) highly suitable areas for $T$. wallichiana would decrease by $31-55 \%$ at a rate of $3-7 \%$ l 10a; (2) moderately suitable areas would decrease by $20-30 \%$ at a rate of $2-4 \% / 10 \mathrm{a}$; (3) the average elevation of potential suitable sites for $T$. wallichiana would shift upslope by $390 \mathrm{~m} \mathrm{(15 \% )} \mathrm{to} 948 \mathrm{~m}(36 \%)$ at a rate of $42-100 \mathrm{~m} / 10 \mathrm{a}$. Average annual temperature (contribution rate ca. $61 \%$ ), isothermality and temperature seasonality (20\%), and annual precipitation (17\%) were the main climatic variables affecting $T$. wallichiana habitats. Prior protected areas and suitable planting areas must be delimited from the future potential distributions, especially the intersection areas at different suitability levels. It is helpful to promote the sustainable utilization of this precious resource by prohibiting exploitation and ex situ restoring wild resources, as well as artificially planting considering climate suitability.

Keywords Taxus wallichiana Zucc. C Climate warming . Potential distribution · MaxEnt · Conservation and cultivation

\section{Introduction}

The Himalaya-Hengduan Mountain (HHM) region is located in the world's Third Pole. It is a biodiversity hotspot and home to Taxus wallichiana Zucc. (Himalayan yew), a relict tree species of the Quaternary glaciation. It is well-known because of taxol, one of the most successful anticancer drugs derived from natural sources. Recent 
research on the taxonomy of Taxus species (Liu et al. 2018) laid the foundation for our study of species distribution and regional conservation. T. wallichiana is the most widely distributed yew in the HHM region. As a relict species from the Quaternary glaciation, it has a history of 2.5 million years on earth and it is known as a living fossil of the plant kingdom. The genus, Taxus, is known for its medicinal value. Taxol was first extracted from $T$. brevifolia in 1971 (Wani et al. 1971). Early experiments demonstrated that taxol could completely inhibit the exponential growth of cancer cells at low concentrations (Schiff et al. 1979). Subsequently, the effectiveness of taxol has been documented for the treatment of various cancers, inflammatory conditions, and Acquired Immune Deficiency Syndrome (Yan et al. 2013; Yang et al. 2017). As one of the most successful anticancer drugs derived from natural sources (Yang et al. 2017), taxol has a huge and expanding market demand (Miao et al. 2015). The bark and leaves of $T$. wallichiana are now used to produce taxol, and this is the reason for its exploitation (Thomas and Farjon 2011; Uniyal 2013). The population in the HHM region has declined significantly $(>50 \%$ in China, $\leq 90 \%$ in Nepal and India) over the last 25-30 years (a single generation) (Thomas and Farjon 2011).

In 1995, T. wallichiana. was assessed as an endangered species by the International Union for Conservation of Nature (IUCN 2018) and trade in the species was regulated by the Convention on International Trade in Endangered Species of Wild Fauna and Flora (CITES 2007). It has been listed as a national first-class protected plant in China (State Forestry Administration of China 1999), and it is on the Negative List of Exports of India (Sajwan and Prakash 2007). Some protected areas are established, e.g., Three Parallel Rivers of Yunnan Protected Areas in China, Sagarmatha National Park in Nepal, and BiDoup-NuiBa National Park in Vietnam. However, in order to restore wild populations or cultivate $T$. wallichiana successfully, the impact of global environmental change (especially climate warming) on $T$. wallichiana must be considered due to its relatively restricted and scattered geographical distribution ( $\mathrm{Su}$ et al. 2005; Thomas and Farjon 2011; Poudel et al. 2014), and its weak ecological adaptability (e.g., poor seed regeneration, long pre-reproductive phase in nature) (Paul et al. 2013; Uniyal 2013). Global climate warming has accelerated (IPCC 2013), especially in areas supporting habitats suitable for $T$ wallichiana in HHM (Fig. S1). Globally, this is affecting the distribution and abundance of species (Hughes 2000; Root et al. 2003; Pacifici et al. 2015; Asner et al. 2016), and is leading to increasing challenges for the conservation of biodiversity (Myers et al. 2000; Pereira et al. 2010; Garcia et al. 2014). Thus, it is important to accurately predict the impact of climate change on species distribution to as a basis for the planning of nature reserves and to protect priority areas for endangered species (Pyke et al. 2005).

Species distribution models (SDMs) which can be drived by Global Climate Model (GCMs) data are powerful tools for predicting species distribution, genetic and evolutionary research, zoning management and protection in the face of climate change. For example, Liu et al. (2013) used molecular biology theories and the MaxEnt model to analyze cryptic speciation and predict changes in the potential distribution of two T. wallichiana lineages [i.e., EH lineage (East Himalaya to the Yunnan Plateau region) and HM lineage (South Hengduan Mountains region)] from the Last Interglacial (LIG, ca. $120 \mathrm{ka}$ ) and Last Glacial Maximum (LGM, ca. $21 \mathrm{ka}$ ) to the present (ca. 1950-2000) in the HHM region. In a warming climate, Poudel et al. (2014) used similar methods to examine genetic diversity and population differentiation, and to predict current and future distributions of three Taxus species (T. contorta, $T$. mairei and $T$. wallichiana) in the Central Himalayas. Gajurel et al. (2014) input climatic variables generated by the HadGEM2-ES climate model into the MaxEnt model to predict the current and future potential distribution of $T$. wallichiana in the Nepal Himalayas. In general, previous predictions of the potential distribution of Taxus species were mainly based on climate scenario datasets generated by single or several climate models. However, due to the complexity of earth's climate systems, as well as the high uncertainty surrounding climate modeling for mountainous regions (due to the paucity of weather stations) (Hijmans et al. 2005), we set out to integrate multiple scenario datasets from multiple climate models to predict the potential distribution of Taxus species.

Our objectives were to: (1) investigate changes in the potential distribution of $T$. wallichiana between current (1960-1990) and future (2050s and 2070s) climate scenarios by integrating three Representative Concentration Pathway (RCP) (i.e., RCP2.6, RCP4.5, RCP8.5) datasets from 14 GCMs of CMIP5 (Coupled Model Intercomparison Project, Phase 5); (2) to quantify the major climatic factors influencing the distribution; and (3) to propose management interventions based on the resulting predictions.

\section{Materials and methods}

\section{Study area}

We set our study area boundaries as $17^{\circ} 50^{\prime} 41^{\prime \prime} \mathrm{N}$ to $33^{\circ} 43^{\prime} 40^{\prime \prime} \mathrm{N}$, and $75^{\circ} 55^{\prime} 52^{\prime \prime} \mathrm{E}$ to $107^{\circ} 38^{\prime} 15^{\prime \prime} \mathrm{E}$ based on the current distribution region of T. wallichiana (Liu et al. 2012, 2013, 2018; Poudel et al. 2014), the species distribution database of the Chinese Virtual Herbarium (CVH), 
and the Global Biodiversity Information Facility (GBIF). This covered an area of $5,478,120 \mathrm{~km}^{2}$, ranging in elevation from 0 to $8000 \mathrm{~m}$ above sea level (Fig. 1). Globally, $T$. wallichiana is mainly distributed in the HHM region. The general circulation pattern in this region is characterized by the influence of Indian and East Asian monsoons in summer, and Westerlies in winter (An et al. 2001; Yao et al. 2012). The habitats currently suitable for $T$. wallichiana in the HHM region are expected to experience intense warming and slight humidification in the future scenarios (Fig. S1).

\section{Data}

\section{Sample data of $T$. wallichiana}

Records for the geographical distribution of $T$. wallichiana were collected from the literature based on the most recent knowledge of the taxonomy of Taxus species in the study area (Liu et al. 2012, 2013, 2018; Poudel et al. 2014). Sixty-nine records were found with species name, longitude, and latitude (Table S1). These data were used to train and validate the current and future distribution simulations of T. wallichiana.

\section{Climate data}

Global climatic data were downloaded from WorldClim (www.worldclim.org) (Hijmans et al. 2005). Among them, the current climate data (1960-1990) were produced based on the observed data in the weather stations using the thinplate smoothing spline algorithm implemented in ANUSPLIN (Hutchinson 2004). The cross-validation error is between 0 and $1{ }^{\circ} \mathrm{C}$ for temperature in most area and less than $10 \mathrm{~mm} /$ month for precipitation in the vast majority of places, respectively, despite the high uncertainty in mountainous areas (see details in Hijmans et al. 2005). The future climate data (outputs of GCMs) were downscaled (interpolated) and calibrated from its original resolution (about two to three geographical degree) to 30 arc-second $\left(0.93 \mathrm{~km} \times 0.93 \mathrm{~km}=0.86 \mathrm{~km}^{2}\right.$ at the equator $)$ using current climate data as the baseline. We downloaded one geographical variable and 19 climatic variables (including the current conditions and predictions for future scenarios (outputs from 14 GCMs)) at a spatial resolution of 30 arcseconds (Table S2). All global spatial data adopted a WGS84 coordinate system and a cylindrical orthographic projection. The climatic data from 1960 to 1990 were used to generate the current potential distribution of $T$.

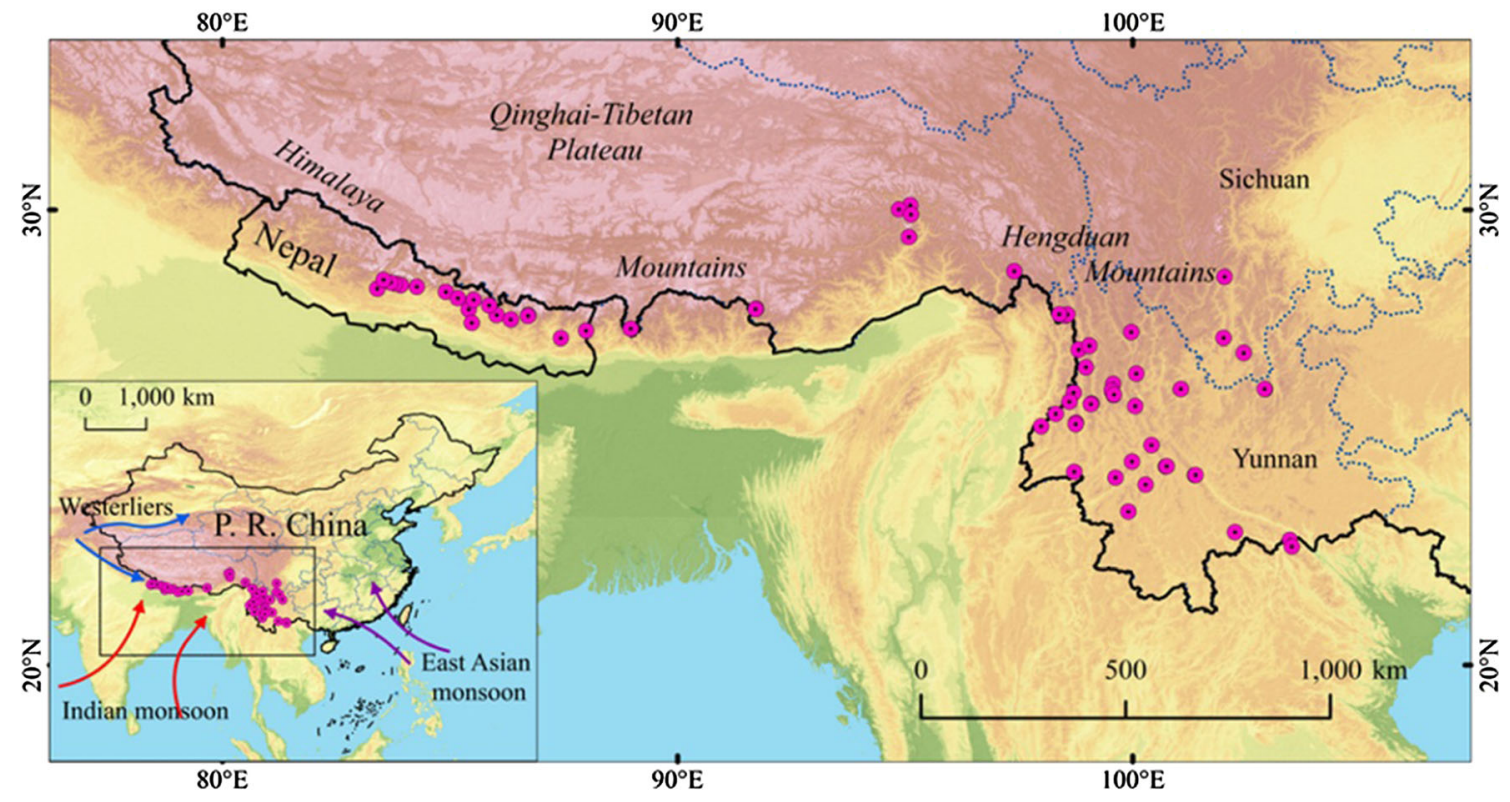

\section{Lengend}

- Sample points

National boundaries

Provincial boundaries

Elevation $(\mathrm{km})$

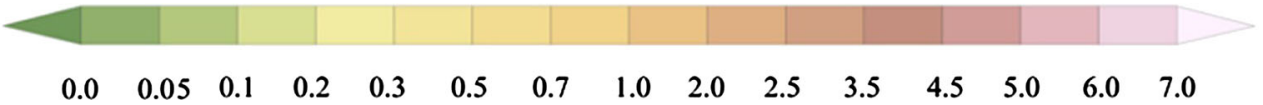

Fig. 1 Study area and sample points of T. wallichiana 
wallichiana, and the climatic data for three scenarios (RCP2.6, RCP4.5, RCP8.5) in the 2050s (2041-2060) and 2070s (2061-2080) outputted from 14 GCMs (Table S3) were used to generate future potential distribution. A total of 20 Climatic and Geographical Variables (20 CGVs) for the HHM region were clipped and extracted, and their spatial resolution, coordinate system and projection were the same as the original spatial data.

To remove multicollinearity among variables, a Pearson's correlation ( $r$ ) matrix (Table S4) was computed with SDMtoolbox 2.0 software (Brown et al. 2017) for all CGVs. Then, the input variables for distribution simulation were selected according to the rule $|r|<0.80$ (Yang et al. 2013; Bosso et al. 2017) combined with the following ecological features of T. wallichiana. In Table S4, CGVs $\mathrm{BIO} 2, \mathrm{BIO} 3$, and $\mathrm{BIO} 15$ were reserved according to the rule $|r|<0.80$. BIO1 was selected among BIO5, BIO6, BIO8, BIO9, BIO10, BIO11 and elevation (topographic variable) because the annual average temperature has a more general and direct impact on plant survival and growth than extreme temperature and elevation (Theurillat and Guisan 2001). Because the study area has a monsoon climate (An et al. 2001; Yao et al. 2012; Schickhoff et al. 2015) (Fig. 1), BIO4 (temperature seasonality) is a more accurate indicator for plant growth and development than BIO7 (annual temperature range). Therefore, BIO4 was reserved. BIO12 was also selected because precipitation is a useful ecological index of $T$. wallichiana's survival. BIO14 (the driest monthly precipitation) and BIO19 (the coldest seasonal precipitation) were also selected as they are the stress variables of $T$. wallichiana under low temperature and dry conditions. As a result, eight CGVs (Table 1) were selected to simulate the current and future potential distribution of $T$. wallichiana.

\section{Methods}

Figure 2 shows the overall technical flowchart. First, CGVs were selected for inputting to the MaxEnt model after eliminating multicollinearity among all variables. Then, the
MaxEnt model was parameterized to simulate the potential distribution of $T$. wallichiana under current and future climate scenarios. The Receiver Operator Characteristic (ROC) analysis and uncertainty analysis (Spatial Inconsistency Rate and Coefficient of Variation for area) were used to validate the simulation accuracy and assess the simulation differences among the 14 climate models. Finally, the spatial and temporal changes in the potential distribution of $T$. wallichiana were investigated, and the percent contribution rate and the response range of influencing factors were detected.

\section{Predicting the potential suitable distribution and the factor contribution rate of $T$. wallichiana}

Based on ecological theories and statistical analyses, SDMs simulate species distribution by relating species observations with environmental variables (Guisan and Zimmermann 2000). The MaxEnt model (Elith et al. 2006; Phillips et al. 2006, 2017) is one SDM which has been widely and successfully applied to the prediction of plant habitats worldwide (Costion et al. 2015; Bocksberger et al. 2016; Booth 2018; Zhang et al. 2018; Dyderski et al. 2018). It is particularly suitable for the prediction of scarce distribution points compared to other presence-only SDMs (Elith et al. 2006; Hernandez et al. 2006; Wisz et al. 2008). Therefore, we used the MaxEnt model (version 3.4.1) to simulate the potential distribution of $T$. wallichiana.

The MaxEnt model was parameterized according to Bosso et al. (2017). First, the sample points of T. wallichiana and the selected eight CGVs for the current and for one of the future scenarios were input to the MaxEnt model. The cross-validation method was adopted for each simulation (Bosso et al. 2017) and 30 replicates were set.

There was a total of 84 simulations (14 GCMs $\times 3$ RCPs $\times 2$ periods). Each simulation simultaneously generated both current and future potential distributions. Because there were 30 replicates for each simulation, the final results could be statistically represented as the mean of 30 replicates to reduce random error. The final average map had a complementary log-log (cloglog) output format
Table 1 List of CGVs selected to predict the current and future potential distribution of $T$. wallichiana

\begin{tabular}{llc}
\hline Code & CGVs & Unit \\
\hline BIO1 & Annual mean temperature & ${ }^{\circ} \mathrm{C}$ \\
BIO2 & Mean diurnal range (mean of monthly (max temp-min temp)) & ${ }^{\circ} \mathrm{C}$ \\
BIO3 & Isothermality (BIO2/BIO7) $(* 100)$ & - \\
BIO4 & Temperature seasonality (standard deviation $* 100)$ & ${ }^{\circ} \mathrm{C}$ \\
BIO12 & Annual precipitation & $\mathrm{mm}$ \\
BIO14 & Precipitation of driest month & $\mathrm{mm}$ \\
BIO15 & Precipitation seasonality (coefficient of variation) & $\mathrm{mm}$ \\
BIO19 & Precipitation of coldest quarter & $\mathrm{mm}$ \\
\hline
\end{tabular}




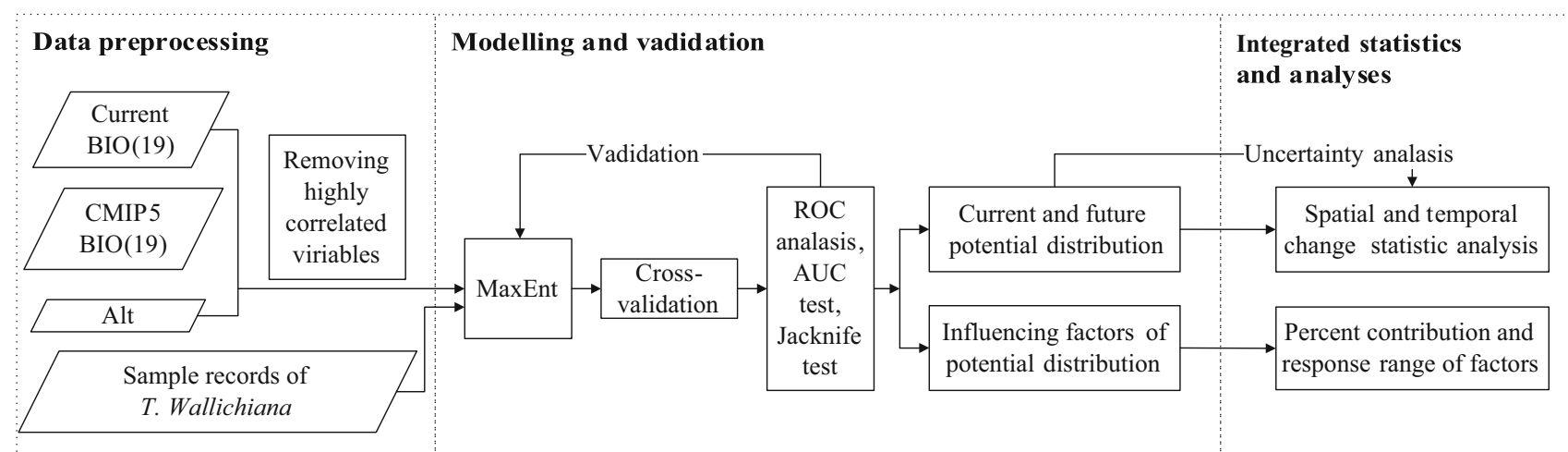

Fig. 2 Technical flowchart

with continuous suitability values from 0 (completely unsuitable habitat) to 1 (most suitable habitat) (Phillips et al. 2017).

The contribution rate for each factor is automaticall computed with the MaxEnt model. It can derive many features for each predictive variable, each of which is a simple mathematical transformation of the predictive variable (Merow et al. 2013). The model assigns the increase in the gain to the predictive variable(s) on which the feature depends. Finally they are converted into percentages to represent the contributions rates (Phillips 2005).

\section{Verifying the simulation performances and differences}

The performance of simulation and the significance of each environmental variable were evaluated by the Area Under Curve (AUC) of ROC with the Jackknife test. Different AUC values indicate different suitable levels: poor $(\mathrm{AUC}<0.80), \quad$ fair $\quad(0.80 \leq \mathrm{AUC}<0.90), \quad$ good $(0.90 \leq$ AUC $<0.95)$, or excellent $(0.95 \leq$ AUC $\leq 1.00)$ (Thuiller et al. 2005).

The Spatial Inconsistent Rate (SIR) was used to evaluate the spatial distribution differences among simulations. First, the common suitable area among the 14 GCMs outputs under the future scenarios was computed (the common suitable area indicates the suitable area intersection of 14 GCMs outputs under the RCPs scenarios.). Then, the SIR was calculated according to formula (1):

$S I R_{i}=\left(S A_{i}-C A\right) / C A \times 100 \%$

where $i$ indicates a single simulation, $S I R_{i}$ the spatial inconsistent rate for the $i$ single simulation, $S A_{i}$ the predicted suitable area for the $i$ single simulation, and $C A$ the common suitable area.
The Coefficient of Variation (CV) for area was used to evaluate the differences of suitable areas at different levels among future scenarios of $14 \mathrm{GCMs}$ outputs. The CV of area was calculated according to formula (2):

$C V_{i j}=u_{i j} / \sigma_{i j}$

where $i$ indicates a future scenario, $j$ a suitable level, $u_{i j}$ the average area among 14 simulations for the $i$ future scenario at the $j$ suitable level, and $\sigma_{i j}$ the standard error.

\section{Classifying the climate suitability level}

The climate suitability level was classified according to the statement of "possibility" in IPCC AR5, which matched the probability results of the MaxEnt model output. The study area was first classified as either a non-suitable area $(0 \leq P<0.05)$ or a suitable area $(0.05 \leq P \leq 1.00)$, and the suitable area was further classified as a marginally suitable $(0.05 \leq P<0.33)$, moderately suitable $(0.33 \leq P<0.66)$, and highly suitable $(0.66 \leq P \leq 1.00)$.

\section{Computing the areas for different levels of suitability}

The predicted results from Maxent had the same spatial resolution, geographic coordinate system and projection as the original data. However, because all the spatial data adopted a cylindrical orthographic projection, the areas for each pixel at different latitudes were not equal. So we first set the area of a pixel at the equator $\left(0.93 \mathrm{~km} \times 0.93 \mathrm{~km}=0.86 \mathrm{~km}^{2}\right)$ as the benchmark, and the area of a pixel at other latitudes was then weighted by the square root of the cosine of its corresponding latitude (Wallace et al. 2000; Marshall et al. 2012). 


\section{Testing statistical significance}

We used paired $t$ test to compare mean simulated areas by suitability level and by elevation between current and future scenarios (Bosso et al. 2017; Liu et al. 2018). The threshold $p<0.05$ was selected to indicate significance of differences between means, and $p<0.01$ indicated extremely significant difference.

\section{Results}

\section{Simulation performances}

Among the 84 simulations, the highest and lowest $\mathrm{AUC}_{\text {training }}$ mean \pm standard values were $0.989 \pm 0.000$, and $0.986 \pm 0.000$, respectively, and the highest and lowest $\mathrm{AUC}_{\text {test }}$ values were $0.987 \pm 0.012$, and $0.984 \pm 0.015$, respectively (Table S5). All the simulations showed excellent performance. Fifty-seven of the 69 actual distribution points were located within the moderately and highly suitable areas of the current predictions (Table S6).

\section{Current and future potential suitable distribution}

T. wallichiana was mainly distributed in the HHM region according to the 84 simulations under the current (1960-1990) condition and the future (2050s and 2070s) scenarios (RCP2.6, RCP4.5, and RCP8.5) (Fig. 3, Fig. S2).
Among the 84 simulations, 57 showed a reduction of the suitable area under future scenarios compared with the current mean condition (Table S7, Table S9).

Significant reduction in suitable area was predicted under the RCP2.5 and RCP4.5 scenarios for the 2050s. The relative reduction ratios (area of reduction to current area, or ratio of reduction) were $11 \%(p<0.05)$ and $9 \%$ $(p<0.05)$ (Table 2), respectively. The relative rates of reduction (the linear regression slope of the relative reduction ratio and year) were $2 \% / 10 \mathrm{a}$ and $1 \% / 10 \mathrm{a}$, respectively (Table 3). No significant reduction in the area of suitable habitat was predicted in other future scenarios. In contrast, a significant increase was predicted under the RCP8.5 scenario for the 2070s, and the relative increase ratio was $21 \%(p<0.05)$ (Table 2$)$. The relative rate of increase was $2 \% / 10$ a (Table 3 ).

The predicted reduction in the area of highly suitable habitat was $11,682(p<0.01)$ to $21,015 \mathrm{~km}^{2}$ $(p<0.001)$, and the relative reduction ratio was $31-55 \%$ (Table 2). The rate of decrease was $1230(p<0.01)$ to $2802(p<0.001) \mathrm{km}^{2} / 10 \mathrm{a}$, and the relative rate of decrease was $3-7 \% / 10$ a (Table 3 ). The predicted reduction in the area of moderately suitable habitat was 15,768 $(p<0.001)$ to $24,064 \mathrm{~km}^{2}(p<0.001)$, and the relative reduction ratio was $20-30 \%$ (Table 2 ). The rate of decrease was 1660 $(p<0.001)$ to $3209(p<0.001) \mathrm{km}^{2} / 10 \mathrm{a}$, and the relative rate of decrease was $2-4 \% / 10$ a (Table 3 ).

In contrast, for the marginally suitable area, a significant increase was predicted under the RCP4.5 and RCP8.5

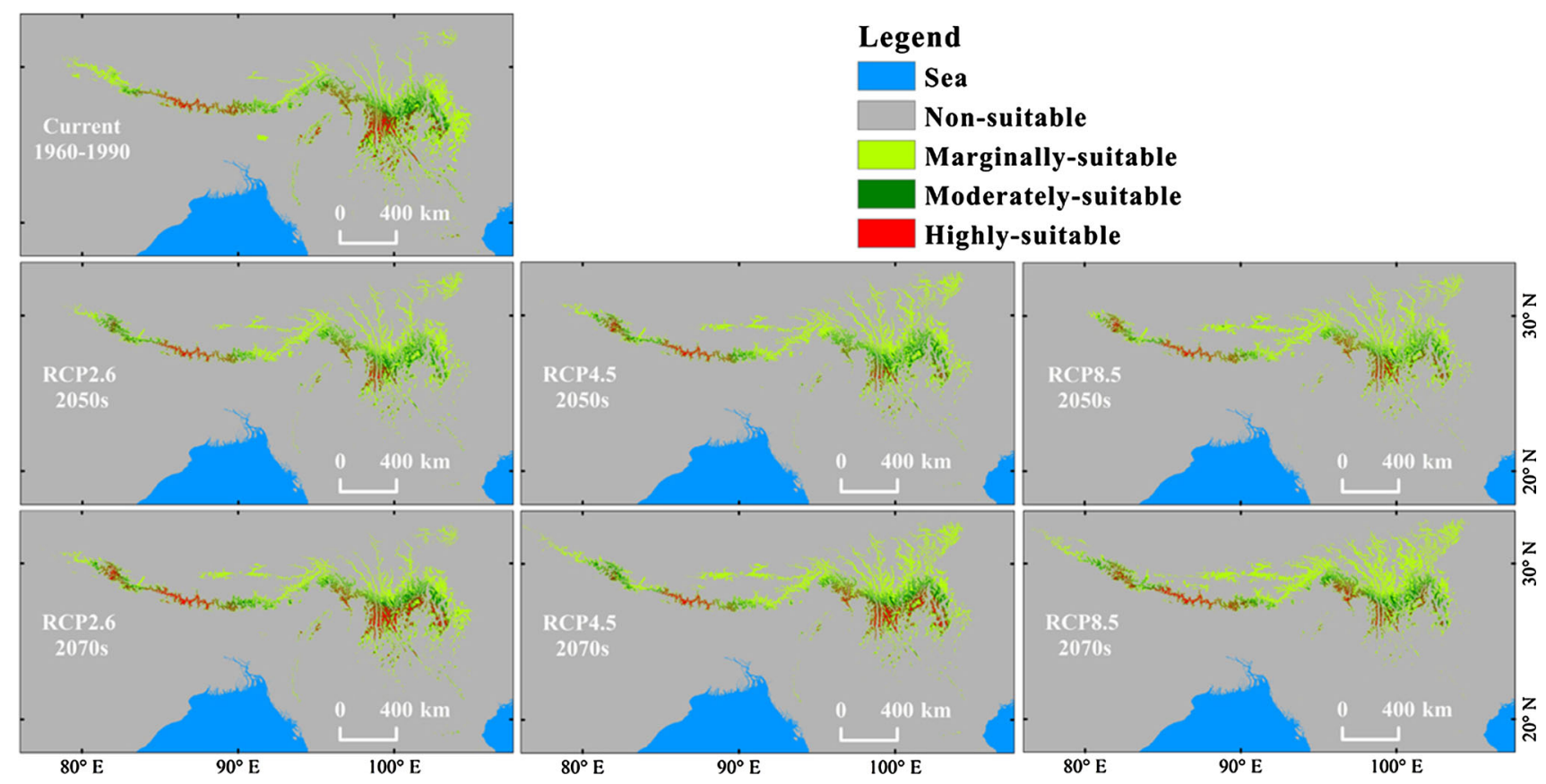

Fig. 3 Distribution of T. wallichiana at different suitable levels under the current condition and the future scenarios based on the BCC-CSM1-1 climate model 


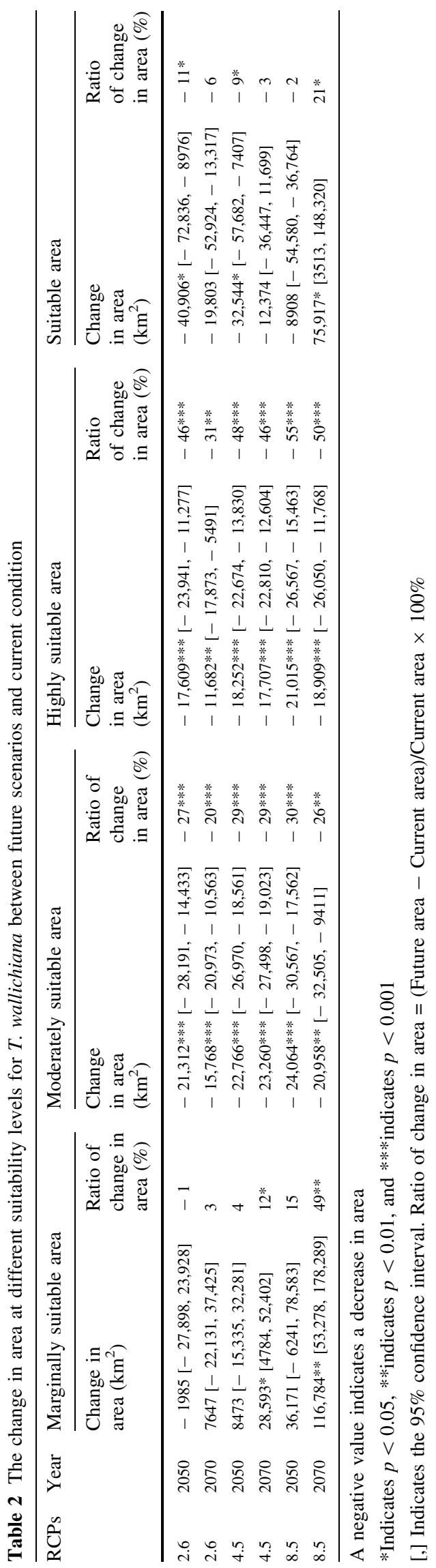




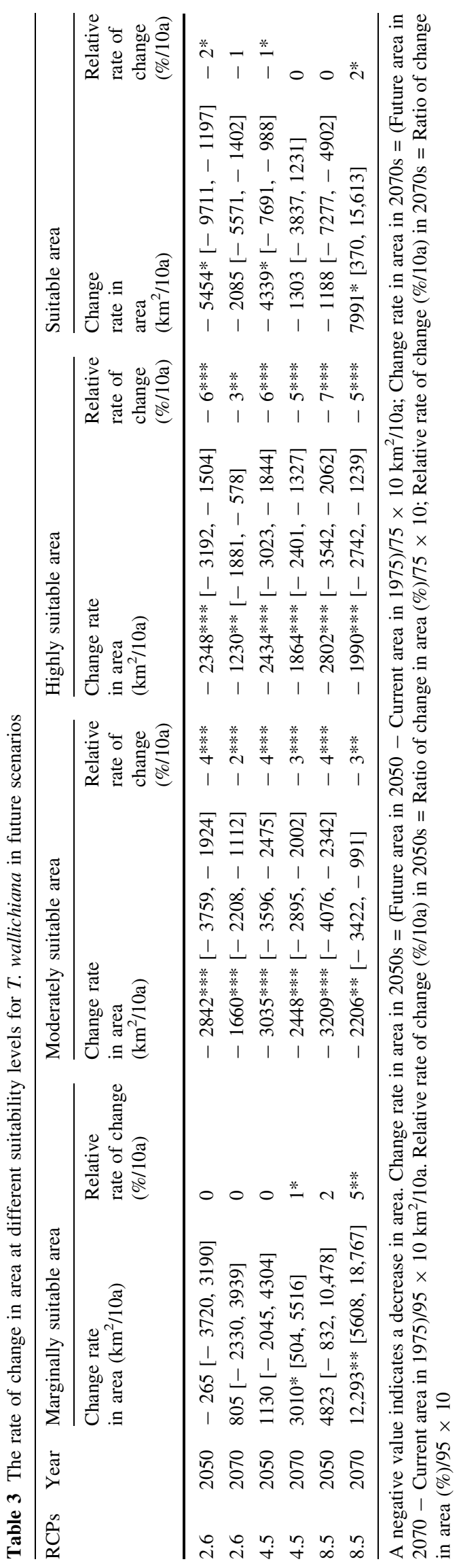



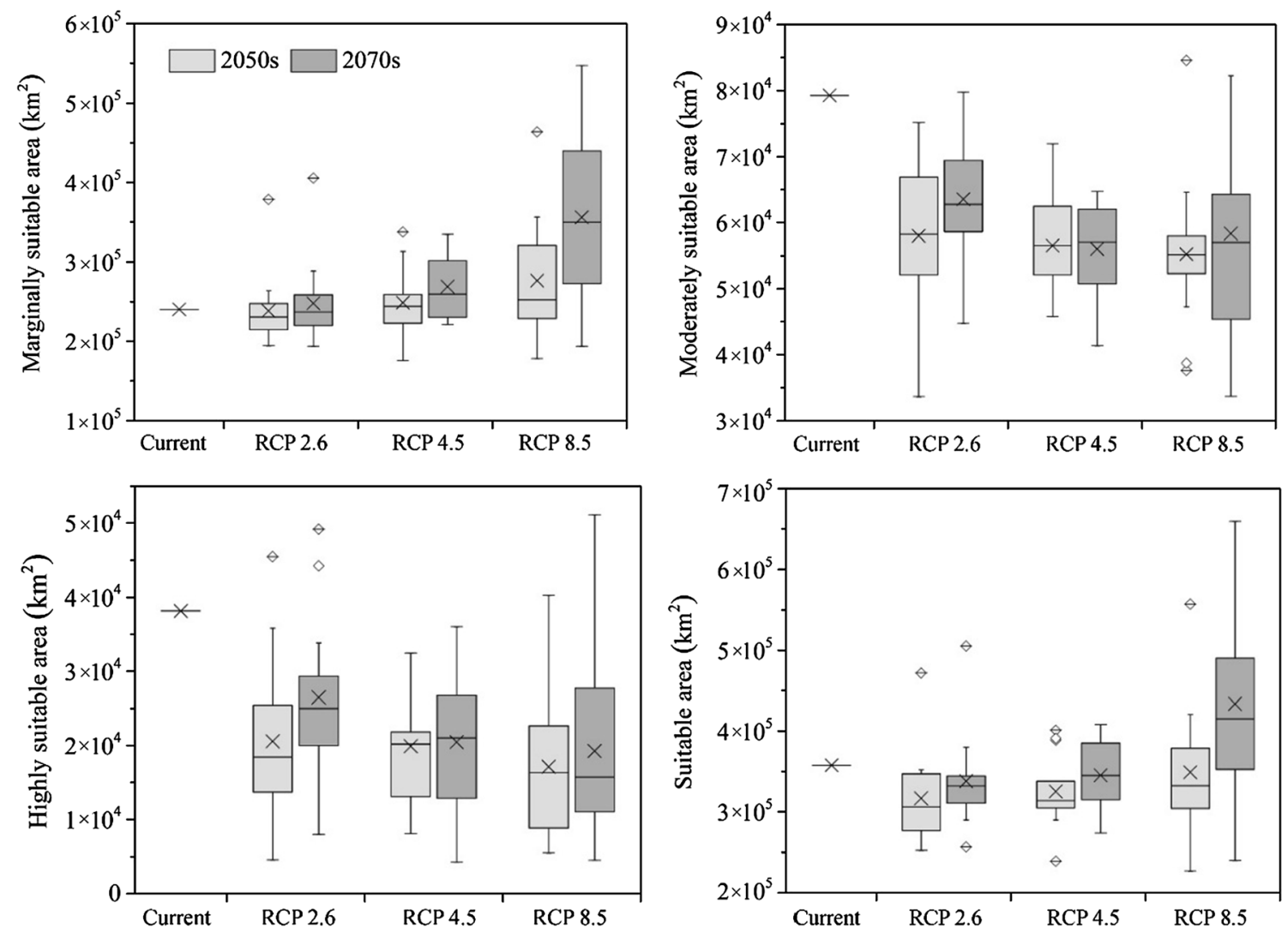

Fig. 4 Boxplot of marginally, moderately, highly suitable, and suitable areas under the current condition and future (2050s, 2070s) scenarios (RCPs) based on 14 GCMs. The bottom and top of the

scenarios for the 2070s. The relative rates of increase were $12 \%(p<0.05)$ and $49 \%(p<0.01)$ (Table 2, Fig. 4$)$, respectively. The relative rates of increase were $1 \% / 10 \mathrm{a}$ and $5 \% / 10$ a, respectively (Table 3 ).

In the future scenarios (2050s and 2070s; RCP2.6, RCP4.5, and RCP8.5), the potential habitat area of $T$. wallichiana was predicted to shift upslope compared with the current condition (Tables 4, 5, Figs. 3, 5, Table S8, Table S10). The average elevation of the potential suitable area was $2633 \pm 14 \mathrm{~m}$ in the current condition (Table S10). It was predicted to shift upslope by $390 \mathrm{~m}$ $(p<0.001), 500 \mathrm{~m}(p<0.001)$, and $627 \mathrm{~m}(p<0.001)$ under the RCP2.6, RCP4.5, and RCP8.5 scenarios, respectively. In the 2070s, it was predicted to shift upslope by $398 \mathrm{~m}(p<0.001), 602 \mathrm{~m}(p<0.001)$, and $948 \mathrm{~m}$ $(p<0.001)$, respectively (Table 4$)$. The ratio of upslope shift in the potential suitable area was $15-36 \%$, and the rate of upslope shift was $42 \mathrm{~m} / 10 \mathrm{a}-100 \mathrm{~m} / 10 \mathrm{a}$ (Table 5).

In the 2050s, the average elevation of the potential highly suitable area was predicted to shift upslope by $288 \mathrm{~m} \quad(p<0.001), \quad 374 \mathrm{~m} \quad(p<0.001)$, and $461 \mathrm{~m}$ $(p<0.001)$ under the RCP2.6, RCP4.5, and RCP8.5 scenarios, respectively. In the $2070 \mathrm{~s}$, it was predicted to shift

boxes are the 25 th and 75 th percentiles; the bands near the middle are the median; the ends of the whiskers represent the minimum and maximum, and the crosses designate the mean value

upslope by $308 \mathrm{~m}(p<0.001), 455 \mathrm{~m}(p<0.001)$, and $743 \mathrm{~m}(p<0.001)$, respectively (Table 4$)$. The ratio of upslope shift in the potential highly suitable area was $10-27 \%$, and the rate of upslope shift was predicted to be 32-78 m/10a (Table 5).

The upslope shift of the moderately suitable and marginally suitable areas were predicted to be greater than the predicted average elevation change of the highly suitable area (see details in Tables 4, 5, and Fig. 5).

\section{Main climatic factors affecting distribution of potentially suitable habitats}

The potential distribution of $T$. wallichiana was mainly influenced by the annual mean temperature (contribution rate ca. $61 \pm 3 \%$ ), annual precipitation (ca. $17 \pm 2 \%$ ), isothermality (ca. $10 \pm 1 \%$ ), and temperature seasonality (ca. $10 \pm 2 \%$ ), which indicated that annual mean temperature and its seasonal variation, as well as annual precipitation, were the main climate variables affecting the habitat of T. wallichiana (Table 6, Table S11). Seasonality of (ca. $1 \pm 0 \%$ ), the precipitation of the coldest quarter (ca. $1 \pm 0 \%$ ), mean diurnal range of temperature (ca. $0 \pm 0 \%$ ), 


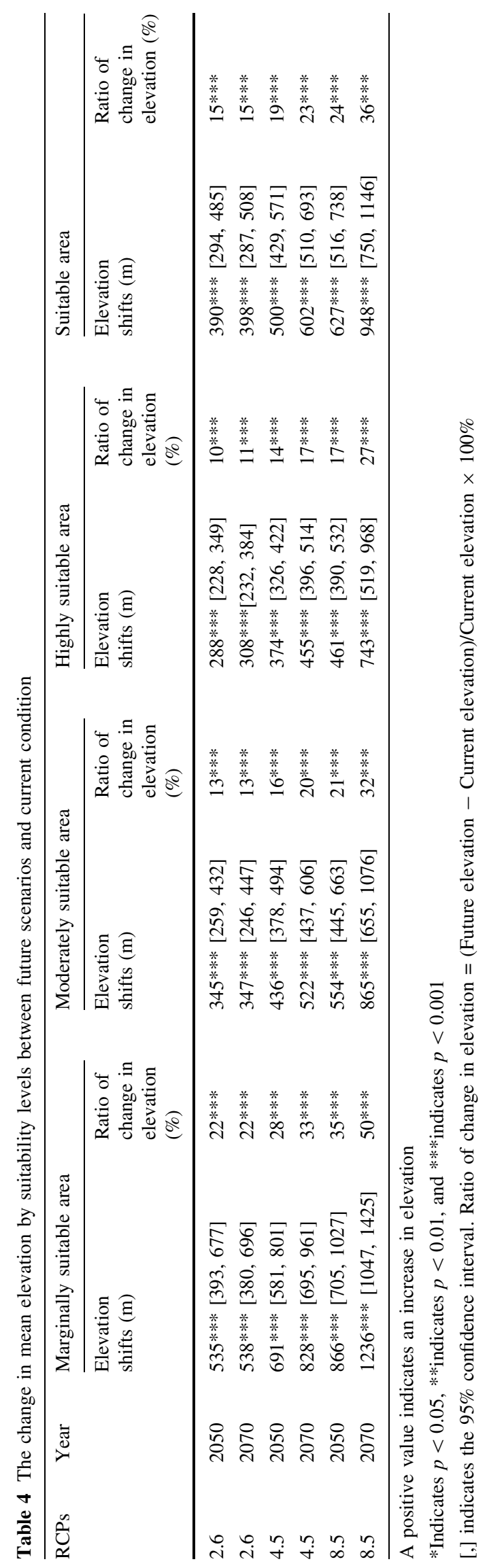




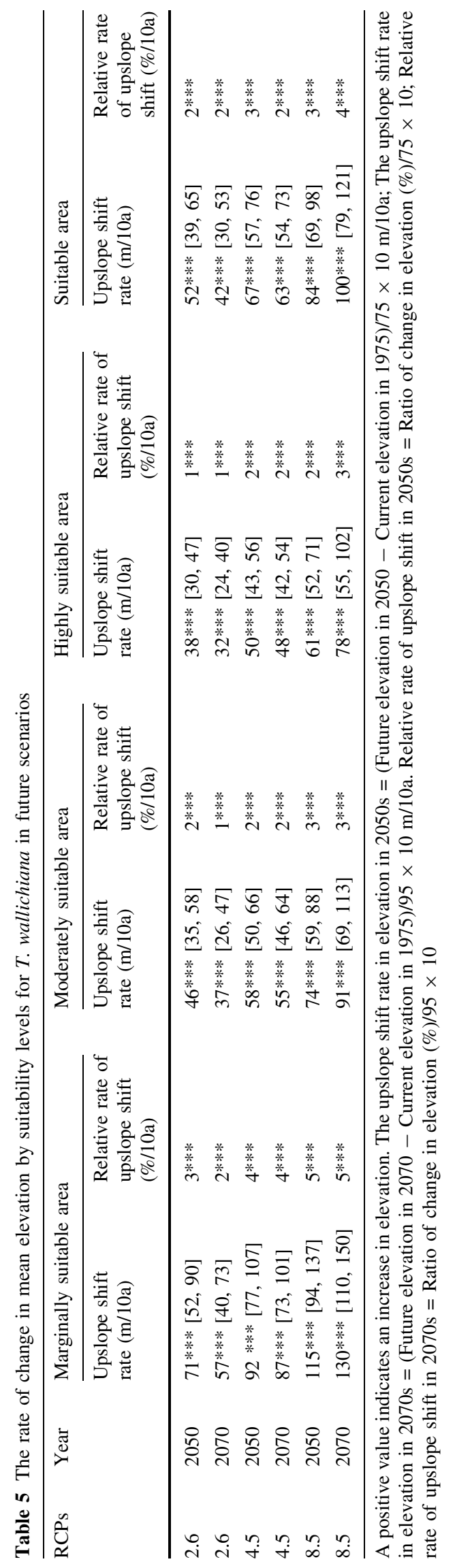



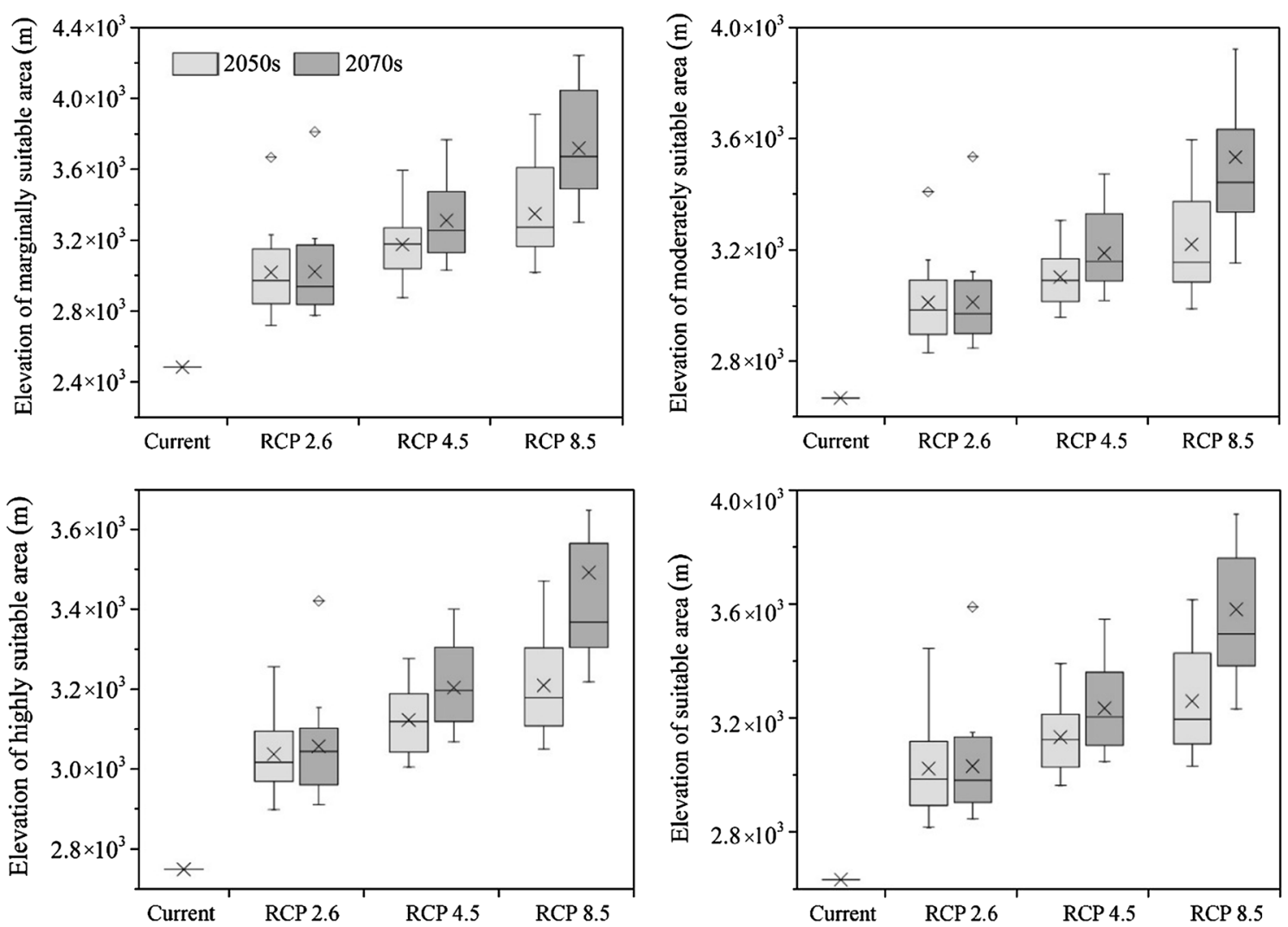

Fig. 5 Boxplot of the elevation of marginally, moderately, highly suitable, and suitable areas under the current condition and future (2050s, 2070s) scenarios (RCPs) based on 14 GCMs. The bottom and

top of the boxes are the 25 th and 75 th percentiles; the bands near the middle are the median; the ends of the whiskers represent the minimum and maximum, and the crosses designate the mean value

Table 6 The contribution rate and probability response curve $(>0.50)$ range of the main climate factors affecting the habitat of $T$. wallichiana

\begin{tabular}{llllc}
\hline Code & CGVs & Unit & Contribution rate (mean \pm SD \%) & Presence probability range $(>0.50)$ \\
\hline BIO1 & Annual mean temperature & ${ }^{\circ} \mathrm{C}$ & $61 \pm 3$ & $8.2-12.6$ \\
BIO12 & Annual precipitation & $\mathrm{mm}$ & $17 \pm 2$ & $950-2450$ \\
BIO3 & Isothermality & - & $10 \pm 1$ & $4.5-5.1$ \\
BIO4 & Temperature seasonality & ${ }^{\circ} \mathrm{C}$ & $10 \pm 2$ & $39-49$ \\
BIO15 & Precipitation seasonality & $\mathrm{mm}$ & $1 \pm 0$ & $79-116$ \\
BIO19 & Precipitation of the coldest quarter & $\mathrm{mm}$ & $1 \pm 0$ & $28-92$ \\
BIO2 & Mean diurnal range of temperature & ${ }^{\circ} \mathrm{C}$ & $0 \pm 0$ & $9.7-11.7$ \\
BIO14 & Precipitation of the driest month & $\mathrm{mm}$ & $0 \pm 0$ & $5-18$
\end{tabular}

and precipitation of the driest month (ca. $0 \pm 0 \%$ ) were other important factors (Table 6, Table S11).

\section{Discussion}

\section{Uncertainties in the simulated potential distribution of T. wallichiana}

Our models predicted substantial differences in the potential area and distribution range of $T$. wallichiana under future climate scenarios (Table 7). Among the differences, the CV for the simulated future suitable areas among 14 GCMs was large (12-29\%), especially for the moderately suitable areas (13-34\%) and the highly suitable areas (38-64\%). Moreover, the SIR for the simulated future suitable areas among $14 \mathrm{GCMs}$ reached $91 \pm 26 \%$ to $259 \pm 104 \%$. These results showed the considerable uncertainty when a single GCM dataset was used, and highlighted the need for integrating multiple scenario datasets from multiple climate models. Some previous research reported considerable uncertainty when using 
Table 7 Coefficient of variation by suitability level and spatial inconsistent rate for suitable area under future scenarios of 14 GCMs

\begin{tabular}{|c|c|c|c|c|c|c|c|c|}
\hline \multirow[t]{2}{*}{ RCPs } & \multirow[t]{2}{*}{ Year } & \multicolumn{4}{|c|}{ Coefficient of variation (\%) } & \multirow{2}{*}{$\begin{array}{l}\text { Common } \\
\text { suitable area }\left(\mathrm{km}^{2}\right)\end{array}$} & \multirow{2}{*}{$\begin{array}{l}\text { Maximum union } \\
\text { suitable area }\left(\mathrm{km}^{2}\right)\end{array}$} & \multirow{2}{*}{$\begin{array}{l}\text { SIR } \\
(\text { mean } \pm \mathrm{SD}) \\
(\%)\end{array}$} \\
\hline & & $\begin{array}{l}\text { Marginally } \\
\text { suitable }\end{array}$ & $\begin{array}{l}\text { Moderately } \\
\text { suitable }\end{array}$ & $\begin{array}{l}\text { Highly } \\
\text { suitable }\end{array}$ & Suitable & & & \\
\hline 2.6 & 2050 & 19 & 21 & 53 & 17 & 164,424 & 621,858 & $93 \pm 34$ \\
\hline 2.6 & 2070 & 21 & 14 & 40 & 17 & 168,755 & 674,525 & $100 \pm 34$ \\
\hline 4.5 & 2050 & 17 & 13 & 38 & 13 & 170,667 & 540,053 & $91 \pm 26$ \\
\hline 4.5 & 2070 & 15 & 13 & 43 & 12 & 165,549 & 620,319 & $109 \pm 25$ \\
\hline 8.5 & 2050 & 27 & 20 & 56 & 23 & 152,326 & 723,429 & $129 \pm 52$ \\
\hline 8.5 & 2070 & 30 & 34 & 64 & 29 & 120,857 & $1,001,640$ & $259 \pm 104$ \\
\hline
\end{tabular}

Common suitable area and maximum union suitable area indicate the intersection and union of suitable area from 14 GCMs outputs under the RCPs scenarios, respectively

GCMs datasets to predict the potential future distribution of species. Bosso et al. (2017) used six GCMs to predict the current and future potential suitable area of the Italian tree pathogen, Diplodia sapinea, and the simulations with different climate models showed large differences. Ikegami and Jenkins (2018) used 14 GCMs to predict the current and future risks of pine wilt disease for 21 pine species based on the MaxEnt model, and the predicted risk area change rate $(\max -\min )$ was greater than $20 \%$ for nearly half of the species among 14 GCMs. Cuyckens et al. (2016) used three GCMs (MIROC-ESM, HAdGEM2-ES, IPSLCM5A-LR) to predict future changes in suitable habitat for Polylepis tarapacana forest in the semi-arid mountainous region of South America. Under the RCP6.0 scenario in 2080, the predicted area with IPSL-CM5A-LR decreased by $42 \%$, while the predicted area with MIROC-ESM decreased by $83 \%$. Wenger et al. (2013) reported that the greatest contribution to uncertainty in predictions of area of suitable habitat was climate uncertainty, followed by the parameter uncertainty and model uncertainty. The variance of future climate (GCMs and SRES) is the largest contributor to the overall uncertainty of the impact of climate change (Bagchi et al. 2013). Integrated forecasting is a promising approach to deal with this uncertainty (Araújo and New 2007). It uses the multi-model inference or multimodel averaging value.

In general, the predictions that use more environmental factors (assuming that multicollinearity is eliminated) can be closer to an actual species ecological niche when considering the uncertainties of environmental factors in simulating potential distribution. Our simulations were mainly based on climatic variables because they are the dominant factors affecting species distribution and change on a regional scale $(>200 \mathrm{~km})$ (Pearson and Dawson 2003). However, on a local scale $(<10 \mathrm{~km})$, the growth of a plant species is affected by other environmental factors, such as soil characteristics (Pearson and Dawson 2003), biological traits (Wang et al. 2018), interspecific competition, and disturbance (Liang et al. 2018). For example, Liang et al. (2016) pointed out that the upslope shift rate of a tree line was largely determined by interspecific relationships (e.g., mutual benefits, interspecific competition and their intensities) with future climate warming. Based on 10-year micro-meteorological observations and a 4-year seedling transplantation experiment of Smith-fir (Abies georgei var. smithii) in the Sergyemla Mountains, southeast Tibet, it was found that climate warming advanced the growth season, which caused early-season freezing, low temperature photoinhibition, and high sunlight significantly reduced seedling survival above the tree line (Shen et al. 2018). Thus, the upslope shift of the tree line will be influenced by multiple factors and become lower than the predicted value based on climate variables. The main distribution area of $T$. wallichiana is located in the high vegetation cover area of southwest China which is an important biodiversity hotspot (Myers et al. 2000). Climate oscillations here have a profound effect on population size (i.e., change, extinction, or promoting local adaptation) (Davis and Shaw 2001), as do the ecological relationships between plant species and other trophic levels (Parmesan and Hanley 2015). Human over-exploitation is an important factor affecting the population of wild T. wallichiana, so the current distribution of the species might not coincide with the most suitable habitat. However, loggers are unlikely to deforest all $T$. wallichiana in the short term (there are no records of deforestation), and the sampling points from the literature were mainly collected in 2010, when the actual distribution of $T$. wallichiana should have been more widespread but was constricted by deforestation. So the simulated current distribution of the species still represented the most suitable and available habitat, and simulated current distribution tended to reflect the potential 
niche of the species rather than the real one, since the biological factors and human activities were not considered.

Comparison and integration of multi-SDMs can help reduce uncertainty in the prediction of species distribution and can optimize prediction results compared with a single SDM. Guo et al. (2018) used 9 SDMs (MaxEnt, SRE, FDA, MARS, GBM, CTA, GLM, ANN and RF) to simulate suitable habitats for Populus euphratica in the Heihe River Basin of China. They found that the spatial distribution of suitable habitats for P. euphratica output from 9 SDMs varied widely, while only the simulation of MaxEnt model accurately depicted the distribution characteristics along the river for $P$. euphratica (verified by remote sensing images). The simulated results in our study also achieved a high accuracy, $83 \%$ observed sample points lay within the moderately and highly suitable areas under the current condition. Moreover, the probability response range (presence probability range $>0.50$ ) for annual mean temperature was $8.2-12.6{ }^{\circ} \mathrm{C}$, similar to the result of $\mathrm{Su}$ et al. (2005) $\left(7.8-11.2{ }^{\circ} \mathrm{C}\right)$.

\section{Changes in the horizontal and vertical potential distribution of $T$. wallichiana}

Compared with the current condition, there were significant and rapid decreases in the highly and moderately suitable habitats for $T$. wallichiana in the future climate scenarios. Poudel et al. (2014) also reported that the potential suitable areas of three yew species in the Central Himalaya would decrease substantially in the future (year 2080) under the A2A and B2A scenarios. Liu et al. (2013) predicted the potential suitable areas of two T. wallichiana lineages in the HHM region with the MaxEnt model and showed that the potential suitable areas in the Last Glacial Maximum (LGM, ca. $21 \mathrm{ka}$ ) were significantly greater than those in the Last Interglacial Period (LIG, ca.120 ka) and in the current climate conditions. Moreover, the potential suitable areas in the Last Interglacial were significantly less than the current climate condition because the temperature in the Last Interglacial was at least $5{ }^{\circ} \mathrm{C}$ higher than the current temperature, which was consistent with the trend of reducing suitable area of $T$. wallichiana due to climate warming (Table 2). There was, however, a significant increase in suitable habitat area for $T$. wallichiana under the RCP8.5 scenario during the 2070s, and this can be related to the change of structure and composition of terrestrial vegetation under a high GHG (global greenhouse gas) emission scenario. IPCC (2013) reported that the rate of warming under the RCP8.5 scenario will be 65 times as high as the average warming during the last deglaciation, and the probability of large compositional changes and large structural changes in terrestrial vegetation are both greater than $60 \%$ under the RCP8.5 scenario (Nolan et al. 2018).

The study also showed that the mean elevations of suitable habitats for T. wallichiana would shift upslope in the future scenarios based on the outputs from multiple climate models. During the Quaternary climatic oscillations, the unique topography in the HHM region provided a climatic gathering place for plant migration (Liu et al. 2013). Global climate warming has promoted plants to migrate to higher elevations and latitudes and this has been confirmed by worldwide observations (Parmesan and Yohe 2003; Lenoir et al. 2008, 2009). Some studies have also predicted that global climate warming will continue to change the distribution of plants by forcing them to move to higher elevations (Huang et al. 2018; Du et al. 2018; Broadhurst et al. 2018). These shifts would lag behind those of climatic changes (Bertrand et al. 2011; Alexander et al. 2018) and significant shifts in elevation would occur only over the long-term (Schickhoff et al. 2015). With global climate warming, Chen et al. (2011) reported that the average upslope shift rate was ca. $11 \mathrm{~m} / 10$ a based on a meta-analysis of 1367 species. Lenoir et al. (2008) observed that the average upslope shift rate of tree species was ca. 29 m/10a in Western Europe. Huang et al. (2018) predicted that future warming could cause Chinese sea buckthorn to shift upslope by $43-128 \mathrm{~m} / 10 \mathrm{a}$. Our results suggested that the potential distribution of $T$. wallichiana could shift upslope by $42-100 \mathrm{~m} / 10 \mathrm{a}$. The larger upslope shifts of suitable habitats in high elevation regions such as the HHM region were related to the strong sensitivity of habitat factors to global warming (Kohler et al. 2010) as well as monsoon interactions (Schickhoff et al. 2015; Huang et al. 2018).

\section{Main climatic factors affecting the potential distribution of $T$. wallichiana}

In general, terrestrial ecosystems are highly sensitive to temperature change (Nolan et al. 2018). As mean annual temperature increases, other ecologically important variables, such as seasonal temperatures, seasonal precipitation, climatic extremes, and degree of variability will change, often in multivariate, complex (Jackson and Overpeck 2000; Jackson et al. 2009), episodic, and nonlinear ways (Millar and Stephenson 2015; Johnstone et al. 2016).

In our study, annual mean temperature consistently contributed $61 \%$ towards the formation of potential suitable habitats for T. wallichiana. Moreover, variation in isothermality and temperature seasonality contributed $20 \%$. This means that with warming climate, the shift in potential suitable habitats for T. wallichiana in the HHM region was mainly controlled by the annual average temperature and 
by temperature variation. On the other hand, the BIO1 (annual mean temperature) was strongly correlated with these variables including BIO5 (maximum temperature of warmest month), BIO6 (minimum temperature of coldest month), BIO8 (mean temperature of wettest quarter), BIO9 (mean temperature of driest quarter), BIO10 (mean temperature of warmest quarter), and BIO11 (mean temperature of coldest quarter), whose Pearson's correlation coefficients were 0.96, 0.99, 0.98, 0.98, 0.99, and 0.99, respectively (Table S4). This indirectly showed that extreme temperatures also played an important role in the formation of potential suitable habitats for T. wallichiana. In addition, this study showed that annual precipitation contributed $17 \%$ to the formation of suitable habitats for $T$. wallichiana. Su et al. (2005) also concluded that the three main climatic factors affecting the geographical distribution of $T$. wallichiana were low temperatures, humidity, and high temperature, in that order.

\section{Management priorities of $T$. wallichiana under climate change}

Areas of highly and moderately suitable habitats for $T$. wallichiana would sharply decline and would shift upslope in future climate scenarios. Therefore, the effective ex situ measures for the scattered mature individuals and seedlings in marginally suitable areas may need to plan based on field investigation and planting experiments.

Macroscopically, a map of potentially suitable areas for T. wallichiana was created by integrating multi-climate model results (Fig. S3-S6). The intersection area of the suitable area at different levels, for example, under the RCP4.5 scenario in 2050s, was more credible than the differential area (union-intersection) and should have priority for protection to ensure the survival of habitats and trees occupying areas that are currently over-exploited due to unprotected. The suitable areas at higher elevations should be prioritized for management. The differential area (union-intersection) has uncertainty, but it retains potential for secondary protection and development in terms of climate suitability. These areas take the intersection as the core area, expand to surrounding areas of mountains and foothills, extend to upper reaches of rivers, or continue to stretch over the high elevation mountainous areas. This accommodates the ecological requirements of $T$. wallichiana under climate warming. However, planting tests are needed to verify this.

The potential suitable habitats for T. wallichiana were mainly located in China, Nepal, India, and Bhutan in the HHM region, so the statutory protection and planting of $T$. wallichiana requires coordinated action between these countries. It is reported that the unlawful logging of yew in China has been severe for nearly a decade, and the number of criminal cases exceeded 1000 (Wang 2018). The exploitation of wild resources must be strictly prohibited through the implementation of laws and policies. Meanwhile, although the cultivation of yew and the industrial extraction of taxol was launched in the late $1990 \mathrm{~s}$, the management of conservation, cultivation, and commercialization still need multi-sectoral efforts. At present, cultivation of yew can be one of the most effective means of utilizing sustainably and protecting the yews what remain in the wild (Thomas and Farjon 2011; TRAFFIC East Asia Report 2007). Among these, the delineation of planting areas will be an important link based on survival rate of yew with respect to climate change. For example, Duque-Lazo et al. (2018) found there was a significant linear positive correlation $\left(r^{2}=0.414, p<0.05\right)$ between the survival rate of cork oak afforestation and the potential probability of presence by predicting the suitable area distribution of cork oak based on SDMs.

\section{Conclusions}

In the future (2050s, 2070s) scenarios (RCP2.6, RCP4.5, RCP8.5), the potentially highly and moderately suitable habitats for T. wallichiana would decline in area, and would shift upslope. Annual mean temperature and seasonal variability in temperature, combined with annual precipitation were the main climate variables affecting the habitat of T. wallichiana. Prior protected areas and suitable planting areas must be delimited from the future potential distributions, especially the intersection areas at different suitability levels. It is helpful to promote the sustainable utilization of this precious resource by prohibiting exploitation and ex situ restoring wild resources, as well as artificially planting considering climate suitability.

Open Access This article is distributed under the terms of the Creative Commons Attribution 4.0 International License (http://crea tivecommons.org/licenses/by/4.0/), which permits unrestricted use, distribution, and reproduction in any medium, provided you give appropriate credit to the original author(s) and the source, provide a link to the Creative Commons license, and indicate if changes were made.

\section{References}

Alexander JM, Chalmandrier L, Lenoir J, Burgess TI, Essl F, Haide S, Kueffer C, McDougall K, Milbau A, Nuñez MA, Pauchard A, Rabitsch W, Rew LJ, Sanders NJ, Pellissier L (2018) Lags in the response of mountain plant communities to climate change. Glob Change Biol 24:563-579

An Z, Kutzbach JE, Prell WL, Porter SC (2001) Evolution of Asian monsoons and phased uplift of the Himalaya-Tibetan plateau since Late Miocene times. Nature 411:62-66

Araújo MB, New M (2007) Ensemble forecasting of species distributions. Trends Ecol Evol 22:42-47 
Asner GP, Brodrick PG, Anderson CB, Vaughn N, Knapp DE, Martin RE (2016) Progressive forest canopy water loss during the 2012-2015 California drought. Proc Natl Acad Sci USA 113:E249-E255

Bagchi R, Crosby M, Huntley B, Hole DG, Butchart SHM, Collingham Y, Kalra M, Rajkumar J, Rahmani A, Pandey M, Gurung H, Trai LT, Quang NV, Willis SG (2013) Evaluating the effectiveness of conservation site networks under climate change: accounting for uncertainty. Glob Change Biol 19:1236-1248

Bertrand R, Lenoir J, Piedallu C, Riofrío-Dillon G, de Ruffray P, Vidal C, Pierrat JC, Gégout JC (2011) Changes in plant community composition lag behind climate warming in lowland forests. Nature 479:517-520

Bocksberger G, Schnitzler J, Chatelain C, Daget P, Janssen T, Schmidt M, Thiombiano A, Zizka G (2016) Climate and the distribution of grasses in West Africa. J Veg Sci 27:306-317

Booth TH (2018) Species distribution modelling tools and databases to assist managing forests under climate change. For Ecol Manag 430:196-203

Bosso L, Luchi N, Maresi G, Cristinzio G, Smeraldo S, Russo D (2017) Predicting current and future disease outbreaks of Diplodia sapinea shoot blight in Italy: species distribution models as a tool for forest management planning. For Ecol Manag 400:655-664

Broadhurst LM, Mellick R, Knerr N, Li L, Supple MA (2018) Land availability may be more important than genetic diversity in the range shift response of a widely distributed eucalypt, Eucalyptus melliodora. For Ecol Manag 409:38-46

Brown JL, Bennett JR, French CM (2017) SDMtoolbox 2.0: the next generation Python-based GIS toolkit for landscape genetic, biogeographic and species distribution model analyses. PeerJ 5:e4095

Chen IC, Hill JK, Ohlemüller R, Roy DB, Thomas CD (2011) Rapid range shifts of species associated with high levels of climate warming. Science 333:1024-1026

CITES (2007) Checklist of CITES species. Retrieved from http:// checklist.cites.org/\#/en/search/output_layout=alphabetical\&le vel_of_listing $=0 \&$ show_synonyms $=1 \&$ show_author $=1 \&$ show english $=1 \&$ show_spanish $=1 \&$ show_french $=1 \&$ scientific_name $=$ Taxus\&page $=1 \&$ per_page $=20$

Costion CM, Simpson L, Pert PL, Carlsen MM, Kress WJ, Crayn D (2015) Will tropical mountaintop plant species survive climate change? Identifying key knowledge gaps using species distribution modelling in Australia. Biol Conserv 191:322-330

Cuyckens GAE, Christie D, Domic A, Malizia LR, Renison D (2016) Climate change and the distribution and conservation of the world's highest elevation woodlands in the South American Altiplano. Glob Planet Change 137:79-87

Davis MB, Shaw RG (2001) Range shifts and adaptive responses to Quaternary climate change. Science 292:673-679

Du H, Liu J, Li MH, Büntgen U, Yang Y, Wang L, Wu Z, He HS (2018) Warming-induced upward migration of the alpine treeline in the Changbai Mountains, northeast China. Glob Change Biol 24:1256-1266

Duque-Lazo J, Navarro-Cerrillo RM, Ruíz-Gómez FJ (2018) Assessment of the future stability of cork oak (Quercus suber L.) afforestation under climate change scenarios in Southwest Spain. For Ecol Manag 409:444-456

Dyderski MK, Paź S, Frelich LE, Jagodziński AM (2018) How much does climate change threaten European forest tree species distributions? Glob Change Biol 24:1150-1163

Elith J, Graham CH, Anderson RP, Dudík M, Ferrier S, Guisan A, Hijmans RJ, Huettmann F, Leathwick JR, Lehmann A, Li J, Lohmann LG, Loiselle BA, Manion G, Moritz C, Nakamura M, Nakazawa Y, Overton JM, Townsend Peterson A, Phillips SJ, Richardson K, Scachetti-Pereira R, Schapire RE, Soberon J,
Williams S, Wisz MS, Zimmermann NE, (2006) Novel methods improve prediction of species' distributions from occurrence data. Ecography 29:129-151

Gajurel JP, Werth S, Shrestha KK, Scheidegger C (2014) Species distribution modeling of Taxus wallichiana (Himalayan Yew) in Nepal Himalaya. Asian J Conserv Biol 3:127-134

Garcia RA, Cabeza M, Rahbek C, Araújo MB (2014) Multiple dimensions of climate change and their implications for biodiversity. Science 344:1247579

Guisan A, Zimmermann NE (2000) Predictive habitat distribution models in ecology. Ecol Model 135:147-186

Guo YL, Li X, Zhao ZF, Wei HY (2018) Modeling the distribution of Populus euphratica in the Heihe River Basin, an inland river basin in an arid region of China. Sci China Earth Sci 61:1669-1684

Hernandez PA, Graham CH, Master LL, Albert DL (2006) The effect of sample size and species characteristics on performance of different species distribution modeling methods. Ecography 29:773-785

Hijmans RJ, Cameron SE, Parra JL, Jones PG, Jarvis A (2005) Very high resolution interpolated climate surfaces for global land areas. Int J Climatol 25:1965-1978

Huang JH, Li GQ, Li J, Zhang XQ, Yan MJ, Du S (2018) Projecting the range shifts in climatically suitable habitat for Chinese sea buckthorn under climate change scenarios. Forests 9:1-11

Hughes L (2000) Biological consequences of global warming: is the signal already apparent? Trends Ecol Evol 15:56-61

Hutchinson MF (2004) Anusplin version 4.3. Centre for Resource and Environmental Studies. The Australian National University, Canberra

Ikegami M, Jenkins TA (2018) Estimate global risks of a forest disease under current and future climates using species distribution model and simple thermal model-Pine Wilt disease as a model case. For Ecol Manag 409:343-352

IPCC (2013) Climate change 2013: the physical science basis. Contribution of working group I to the fifth assessment report of the intergovernmental panel on climate change. Cambridge University Press, Cambridge

IUCN (2018) The IUCN red list of threatened species. Version 2018-1. Retrieved from http://www.iucnredlist.org

Jackson ST, Overpeck JT (2000) Responses of plant populations and communities to environmental changes of the late Quaternary. Paleobiology 26:194-220

Jackson ST, Betancourt JL, Booth RK, Gray ST (2009) Ecology and the ratchet of events: climate variability, niche dimensions, and species distributions. Proc Natl Acad Sci USA 106:19685-19692

Johnstone JF, Allen CD, Franklin JF, Frelich LE, Harvey BJ, Higuera PE, Mack MC, Meentemeyer RK, Metz MR, Perry GLW, Schoennage T, Turne MG (2016) Changing disturbance regimes, ecological memory, and forest resilience. Front Ecol Environ 14:369-378

Kohler T, Giger M, Hurni H, Ott C, Wiesmann U, von Dach SW, Maselli D (2010) Mountains and climate change: a global concern. Mt Res Dev 30:53-55

Lenoir J, Gégout JC, Marquet P, De Ruffray P, Brisse H (2008) A significant upward shift in plant species optimum elevation during the 20th century. Science 320:1768-1771

Lenoir J, Gégout JC, Pierrat JC, Bontemps JD, Dhôte JF (2009) Differences between tree species seedling and adult altitudinal distribution in mountain forests during the recent warm period (1986-2006). Ecography 32:765-777

Liang EY, Wang YF, Piao SL, Lu XM, Camarero JJ, Zhu HF, Zhu LP, Ellison AM, Ciais P, Peñuelas J (2016) Species interactions slow warming-induced upward shifts of treelines on the Tibetan Plateau. Proc Natl Acad Sci USA 113:4380-4385 
Liang Y, Duveneck MJ, Gustafson EJ, Serra-Diaz JM, Thompson JR (2018) How disturbance, competition, and dispersal interact to prevent tree range boundaries from keeping pace with climate change. Glob Chang Biol 24:e335-e351

Liu J, Provan J, Gao LM, Li DZ (2012) Sampling strategy and potential utility of indels for DNA barcoding of closely related plant species: a case study in Taxus. Int J Mol Sci 13:8740-8751

Liu J, Möller M, Provan J, Gao LM, Poudel RC, Li DZ (2013) Geological and ecological factors drive cryptic speciation of yews in a biodiversity hotspot. New Phytol 199:1093-1108

Liu J, Milne RI, Möller M, Zhu GF, Ye LJ, Luo YH, Yang JB, Wambulwa MC, Wang CN, Li DZ, Gao LM (2018) Integrating a comprehensive DNA barcode reference library with a global map of yews (Taxus L.) for forensic identification. Mol Ecol Resour 0:1-17

Marshall AG, Hudson D, Wheeler MC, Hendon HH, Alves O (2012) Simulation and prediction of the Southern Annular Mode and its influence on Australian intra-seasonal climate in POAMA. Clim Dyn 38:2483-2502

Merow C, Smith MJ, Silander JA Jr (2013) A practical guide to MaxEnt for modeling species' distributions: what it does, and why inputs and settings matter. Ecography 36:1058-1069

Miao YC, Su JR, Zhang ZJ, Lang XD, Liu WD, Li SF (2015) Microsatellite markers indicate genetic differences between cultivated and natural populations of endangered Taxus yunnanensis. Bot J Linn Soc 177:450-461

Millar CI, Stephenson NL (2015) Temperate forest health in an era of emerging megadisturbance. Science 349:823-826

Myers N, Mittermeier RA, Mittermeier CG, Da Fonseca GA, Kent J (2000) Biodiversity hotspots for conservation priorities. Nature 403:853-858

Nolan C, Overpeck JT, Allen JR, Anderson PM, Betancourt JL, Binney HA, Brewer S, Bush MB, Chase BM, Cheddadi R, Djamali M, Dodson J, Edwards ME, Gosling WD, Haberle S, Hotchkiss SC, Huntley B, Ivory SJ, Kershaw AP, Kim SH, Latorre C, Leydet M, Lézine AM, Liu KB, Liu Y, Lian-Ming LA, Gao V, McGlone MS, Marchant RA, Momohara A, Moreno PI, Müller S, Otto-Bliesner BL, Shen C, Stevenson J, Takahara $\mathrm{H}$, Tarasov PE, Tipton J, Vincens A, Weng C, Xu Q, Zheng Z, Jackson ST (2018) Past and future global transformation of terrestrial ecosystems under climate change. Science 361:920-923

Pacifici M, Foden WB, Visconti P, Watson JE, Butchart SH, Kovacs KM, Scheffers BR, Hole DG, Martin TG, Akcakaya HR, Corlett RT, Huntley B, Bickford D, Carr JA, Hoffmann AA, Midgley GF, Pearce-Kelly P, Pearson RG, Williams SE, Willis SG, Young B, Rondinini C (2015) Assessing species vulnerability to climate change. Nat Clim Change 5:215-224

Parmesan C, Hanley ME (2015) Plants and climate change: complexities and surprises. Ann Bot 116:849-864

Parmesan C, Yohe G (2003) A globally coherent fingerprint of climate change impacts across natural systems. Nature 421:37-42

Paul A, Bharali S, Khan ML, Tripathi OP (2013) Anthropogenic disturbances led to risk of extinction of Taxus wallichiana Zuccarini, an endangered medicinal tree in Arunachal Himalaya. Nat Area J 33:447-454

Pearson RG, Dawson TP (2003) Predicting the impacts of climate change on the distribution of species: are bioclimate envelope models useful? Glob Ecol Biogeogr 12:361-371

Pereira HM, Leadley PW, Proença V, Alkemade R, Scharlemann JP, Fernandez-Manjarrés JF, Araújo MB, Balvanera P, Biggs R, Cheung WWL, Chini L, Cooper HD, Gilman EL, Guénette S, Hurtt GC, Huntington HP, Mace GM, Oberdorff T, Revenga C, Rodrigues P, Scholes RJ, Sumaila UR, Walpole M (2010)
Scenarios for global biodiversity in the 21 st century. Science 330:1496-1501

Phillips SJ (2005) A brief tutorial on Maxent. AT\&T Research, Middletown

Phillips SJ, Anderson RP, Schapire RE (2006) Maximum entropy modeling of species geographic distributions. Ecol Model 190:231-259

Phillips SJ, Anderson RP, Dudík M, Schapire RE, Blair ME (2017) Opening the black box: an open-source release of Maxent. Ecography 40:887-893

Poudel RC, Möller M, Liu J, Gao LM, Baral SR, Li DZ (2014) Low genetic diversity and high inbreeding of the endangered yews in Central Himalaya: implications for conservation of their highly fragmented populations. Divers Distrib 20:1270-1284

Pyke CR, Andelman SJ, Midgley G (2005) Identifying priority areas for bioclimatic representation under climate change: a case study for Proteaceae in the Cape Floristic Region, South Africa. Biol Conserv 125:1-9

Root TL, Price JT, Hall KR, Schneider SH, Rosenzweig C, Pounds JA (2003) Fingerprints of global warming on wild animals and plants. Nature 421:57-60

Sajwan BS, Prakash KC (2007) Conservation of medicinal plants: conventional and contemporary strategies, regulations and executions. Indian For 133:484-495

Schickhoff U, Bobrowski M, Böhner J, Bürzle B, Chaudhary R, Gerlitz L, Heyken H, Lange J, Müller M, Scholten T, Schwab N, Wedegärtner R (2015) Do Himalayan treelines respond to recent climate change? An evaluation of sensitivity indicators. Earth Syst Dyn 5:1407-1461

Schiff PB, Fant J, Horwitz SB (1979) Promotion of microtubule assembly in vitro by taxol. Nature 277:665-667

Shen W, Zhang L, Guo Y, Luo TX (2018) Causes for treeline stability under climate warming: evidence from seed and seedling transplant experiments in southeast Tibet. For Ecol Manag 408:45-53

State Forestry Administration of China (1999) A list of national key protected wild plants in China (first batch). http://www.gov.cn/ gongbao/content/2000/content_60072.htm

Su JR, Zhang ZJ, Deng J, Li GS (2005) Relationships between geographical distribution of Taxus wallichiana and climate in China. For Res 18:510-515 (in Chinese)

Theurillat JP, Guisan A (2001) Potential impact of climate change on vegetation in the European Alps: a review. Clim Change 50:77-109

Thomas P, Farjon A (2011) Taxus wallichiana. The IUCN red list of threatened species 2011:e.T46171879A9730085.http://dx.doi. org/10.2305/IUCN.UK.2011-2.RLTS.T46171879A9730085.en

Thuiller W, Richardson DM, Pyšek P, Midgley GF, Hughes GO, Rouget M (2005) Niche-based modelling as a tool for predicting the risk of alien plant invasions at a global scale. Glob Change Biol 11:2234-2250

TRAFFIC East Asia Report (2007) Trade and conservation of Taxus in China. https://www.traffic.org/site/assets/files/5211/conserva tion-taxus-in-china.pdf

Uniyal SK (2013) Bark removal and population structure of Taxus wallichiana Zucc. in a temperate mixed conifer forest of western Himalaya. Environ Monit Assess 185:2921-2928

Wallace JM, Thompson DW, Fang Z (2000) Comments on "Northern Hemisphere teleconnection patterns during extreme phases of the zonal-mean circulation". J Clim 13:1037-1039

Wang L (2018) Endangered yew in the past 20 years, ThePaper.cn. Retrieved from https://www.thepaper.cn/newsDetail_forward_ 2248908 (in Chinese)

Wang WJ, He HS, Thompson FR, Spetich MA, Fraser JS (2018) Effects of species biological traits and environmental 
heterogeneity on simulated tree species distribution shifts under climate change. Sci Total Environ 634:1214-1221

Wani MC, Taylor HL, Wall ME, Coggon P, McPhail AT (1971) Plant antitumor agents. VI. The isolation and structure of taxol, a novel antileukemic and antitumor agent from Taxus brevifolia. J Am Chem Soc 93:2325-2327

Wenger SJ, Som NA, Dauwalter DC, Isaak DJ, Neville HM, Luce CH, Dunham JB, Young MK, Fausch KD, Rieman BE (2013) Probabilistic accounting of uncertainty in forecasts of species distributions under climate change. Glob Change Biol 19:3343-3354

Wisz MS, Hijmans R, Li J, Peterson AT, Graham C, Guisan A, NCEAS Predicting Species Distributions Working Group (2008) Effects of sample size on the performance of species distribution models. Divers Distrib 14:763-773

Yan CY, Yin Y, Zhang DW, Yang W, Yu RM (2013) Structural characterization and in vitro antitumor activity of a novel polysaccharide from Taxus yunnanensis. Carbohydr Polym 96:389-395
Yang XQ, Kushwaha S, Saran S, Xu J, Roy P (2013) Maxent modeling for predicting the potential distribution of medicinal plant, Justicia adhatoda L. in Lesser Himalayan foothills. Ecol Eng 51:83-87

Yang L, Ruan X, Gao XX, Zhang H, Wang Q (2017) Morphological characteristics, geographical distribution, secondary metabolites, and biological activities of Taxus. Mini Rev Org Chem $14: 217-226$

Yao TD, Thompson L, Yang W, Yu WS, Gao Y, Guo XJ, Yang XX, Duan KQ, Zhao HB, Xu BQ, Pu JC, Lu AX, Xiang Y, Kattel DB, Joswiak D (2012) Different glacier status with atmospheric circulations in Tibetan Plateau and surroundings. Nat Clim Change 2:663-667

Zhang KL, Yao LJ, Meng JS, Tao J (2018) Maxent modeling for predicting the potential geographical distribution of two peony species under climate change. Sci Total Environ 634:1326-1334

Publisher's Note Springer Nature remains neutral with regard to jurisdictional claims in published maps and institutional affiliations. 